International Journal of Health Sciences
Available online at www.sciencescholar.us
Vol. 5 No. 1, January 2021, pages: 20-28
ISSN: 2550-6978 E-ISSN: 2550-696X
https://doi.org/10.29332/ijhs.v5n1.700

\title{
Educational Innovation in the Comprehensive Training of Nursing Graduates
}

\author{
María del Rosario Herrera Velázquez ${ }^{1}$, Adis Anicia Luna Báez² ${ }^{2}$ Ariagna Martínez Pérez³ ${ }^{3}$ Anaysa \\ Alvarez Luna ${ }^{4}$
}

Manuscript submitted: 09 November 2020, Manuscript revised: 27 December 2020, Accepted for publication: 18 January 2021

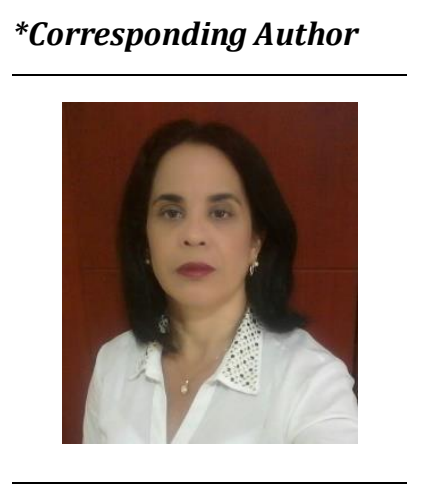

\section{Keywords}

basic training;

interdisciplinarity;

nursing;

specialization;

teacher training;

\begin{abstract}
Multi and interdisciplinary teamwork was developed on the integration of basic sciences among themselves and their contribution to professional training. Work was done on the identification of essentialities, organization, and structuring of contents according to the requirements and precedence relationships of the Nursing discipline. The general objective was to identify the interdisciplinary relationships between the basic sciences of the nursing career to improve the quality of teaching. A qualitative and descriptive study was carried out through a historical-logical analysis based on documents, syllables, teachers of the basic training semesters, and students. Interviews with teachers and student surveys were applied and it was found that there is a need to develop methodological career work aimed at disciplinary integration. Failures were detected such as an inadequate perception of the students about the role of interdisciplinarity in their training, no planning of methodological career activities that promote interdisciplinarity, dissatisfaction with integration in knowledge-integrating projects, and the need for methodological proposals for the interdisciplinarity from the first year of the degree. Integration of the contents was achieved with an inter and transdisciplinary approach, which is recognized as having a favorable impact on academic success and the quality of teacher training.
\end{abstract}

\section{Contents}

Abstract

\footnotetext{
${ }^{1}$ Universidad Estatal del Sur de Manabí, Jipijapa, Manabí, Ecuador

${ }^{2}$ Universidad Estatal del Sur de Manabí, Jipijapa, Manabí, Ecuador

${ }^{3}$ Universidad Estatal del Sur de Manabí, Jipijapa, Manabí, Ecuador

${ }^{4}$ Hospital MSP de Pedro Carbo, Jipijapa, Manabí, Ecuador
} 
2 Materials and Methods.

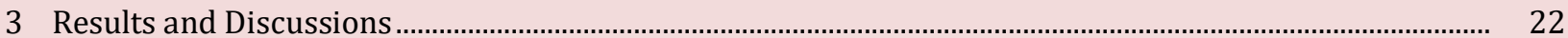

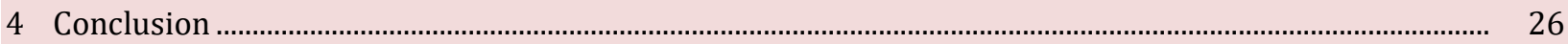



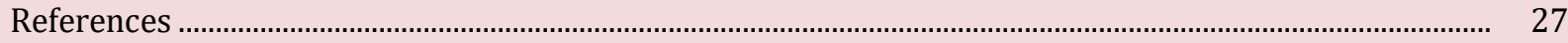

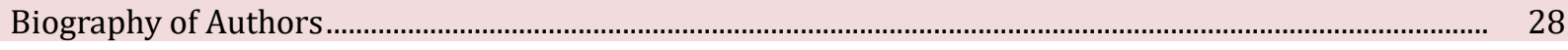

\section{Introduction}

Higher education with very concrete actions, under the principle of the relevance of university institutions, expressed in their ability to act following the interests and needs of the country, as a continuous process of transformation aimed at expanding possibilities and opportunities access to university, to multiply and extend knowledge to contribute to the formation of a comprehensive general culture of the population, with a sustained increase inequity and social justice has been empowered with the implementation of the TO INN project of which the State University of the South of Manabí is a partner. In Latin America, the growing interest in the search for greater integration in the most varied forms has allowed the concept of division or specialization by areas of knowledge to take shape and the Faculty of Health Sciences appears as a more general level of interprofessional integration.

In reality, no single event can justify the perpetuation of existing traditional schemes. Neither the force of positivism and constructivism, with their hierarchy of the sciences, nor the influence exerted by the prevailing tendency towards a deductive theoretical approach, would be sufficient reasons to explain such a situation. New integrative solutions may be poorly understood among some "basic" scientists, which could lead to resistance to change; or that at the clinical level, by a defense mechanism, a blockade of the interpenetration of basic personnel is established, considering the recent trend that students related to health care acquire better scientific training and begin to develop research to the integration of their knowledge in integrating knowledge projects and recognize the interdisciplinary relationship of these subjects for the systematization of their knowledge in nursing practice.

Interdisciplinarity offers an instrument for change and enables the now potentially feasible approach of the relocation of scientific knowledge in an integrative vision of the training of future nursing professionals. The three subjects under discussion Biochemistry, morphophysiology, and Pharmacology are taught in the first and second semesters of the nursing career. Being basic foundations for the development of students' knowledge and to understand the other disciplines that make up the curricular design of the Nursing career.

Is biochemical knowledge significantly different from knowledge obtained in morphophysiology and pharmacology? That is, does biochemistry exist in a completely different form from the objects of the physiological question? If this is true, how can the extraordinary utility of biochemistry for morphophysiology be explained? The latter studies the functions of the organism, and biochemistry represents the very substrate of these functions with the study of the essence of cellular metabolism. More than a difference in the body of knowledge on these subjects, one could speak of hierarchical levels, in the sense that the biochemistry of man is contained in Human Morphophysiology, although the latter may include axioms of another nature that exceed the limits of biochemistry.

Pharmacology is a matter of integration, which is supported by knowledge from these basic disciplines, it also presents a large volume of information, which increases exponentially due to the increasing advances in molecular pharmacology incorporating complex content, difficult to understand. Students present difficulties in learning and the persistence of what they have learned, for several reasons, among these, they lack the necessary integration of knowledge, because of having received excessive disjointed information, they assume a passive attitude, playing the role of receptors within a unidirectional communication, limiting themselves to receiving information, they lack support images, necessary for understanding and fixing abstract content and they access scattered information, which forces them to investigate different sources (Wik et al., 2002; Chamberlain et al., 2002). Logical thinking finds pedagogical resonance, when the subjects contain a sufficient number of cross-references between them or if they refer to a sufficient number of common sources and scientific knowledge practices the same discipline if common aspects are analyzed such as: they have a non-

Velázquez, M. del R. H., Báez, A. A. L., Pérez, A. M., \& Luna, A. A. (2021). Educational innovation in the comprehensive training of nursing graduates. International Journal of Health Sciences, 5(1), 20-28. https://doi.org/10.29332/ijhs.v5n1.700 
identical education but sufficiently similar; they are infrequent interaction in terms of cognitive points; they perform similar actions and belong to a sufficient number of common professional institutions.

In general, the inquiry has its origin in a conceptual structure, that structure determines the questions that can be asked in the inquiry, the questions determine the data that is needed, and the researcher decides the procedures that must be followed. In the present case, the difference between the aforementioned disciplines could be registered at a procedural level, but it would not be sufficient to reach the conceptual structure in which the question of the physiological sciences must be framed (Guasch et al., 2010; Kyriakides et al., 2009). It would still be necessary to determine, for each discipline, what she is looking for in terms of discovery or evidence: what criteria does she use to measure the quality of her information? How strictly do you apply to your evidence? And, in general, by what paths does the discipline move from its basic information to the conclusions? In this analysis of the syntactic structure of the three disciplines, it is found that in all of them the application of the scientific method is centered on an experimental model, in which, of course, certain specific procedures can vary.

The analysis model revolves around:

1) The structural base,

2) Energy contribution and regulation of functional activities of living organisms.

3) The quality criteria also include tactical aspects in the design of the experiments, aspects of skill in their execution, and statistical validity of the information obtained

4) Energy exchanges and the interactions of chemical products and living systems help to explain vital processes and also provide effective methods for the treatment, prevention, and diagnosis of many diseases.

It can be admitted that as the basic sciences are integrated, the respective human teams will tend to reorganize according to their specialized interests. When the history of science is analyzed and it is realized that it is both a history of knowledge specializations and a history of integration into a general culture of specialized cultures. The evidence of the implementation and importance of interdisciplinarity is diverse. Thus, for example, educational strategies focused on this are implemented, various disciplines, subjects, or subjects (depending on the classification of each region or country) share an object of study, approach, or research methodologies, achieving communication and coordination of the contents and hence of knowledge. Another example is the formation of interdisciplinary research groups and the generation and execution of projects with the same characteristics, which sometimes ruin the formation of institutes, centers, or foundations in which various areas of knowledge are present, with a common objective, that of contributing to social development through proposals for solutions to local, regional, national or even global problems (Salcedo Monsalve, s / f). For all of the above, the authors undertook the task of identifying the interdisciplinary relationships between the basic sciences of the nursing career to improve the quality of teaching.

\section{Materials and Methods}

A qualitative study was carried out, with a descriptive methodology, executed through theoretical methods such as historical-logical analysis, abstraction, carried out in the analysis of documents, syllables, groups of teachers of these semesters of basic training for analyzing the results of learning in these basic sciences; Interviews with teachers and student surveys were applied to inquire about the integration and systematization of the contents and students' knowledge about the subject.

\section{Results and Discussions}

The nursing career at the State University of the South of Manabí responds to a curriculum based on the construction of knowledge related to basic sciences, research, health promotion, and prevention. During the study time that the degree lasts, the student will also develop values that are part of UNESUM, such as the link with society, social responsibility, entrepreneurship, and leadership (Placencia López et al., 2018). For the graduate in nursing and therefore for the professional in training, training by applying an interdisciplinary 
approach will allow them to expand the level of analysis of the problems that arise, taking into account that the essence of nursing action is care, which has as a base the North American classical theories, whose representative figures are Florence Nightingale, Dorothea Orem, Virginia Henderson, and Madeleine Leininger. It also prepares them to understand other disciplines related to nursing and research this, so that they can make novel contributions and not only evaluate care (Martínez Trujillo \& Torres Esperón, 2014).

The teaching staff of the nursing career at UNSUM is made up of a total of 46 teachers, 26 of them graduated in nursing (with a fourth level degree in different specialties of this science and of the 16 in the process of doctoral training). 7 doctors of medicine (with master's degrees and/or medical specialties), a doctor of science (Ph.D.) in pharmacy, three pedagogues, including two doctors of this science (Ph.D.), two professors of physical culture, a lawyer, a dentist, Two economists, a commercial engineer, a graduate in history and geography and an English language teacher, in addition to this, five English language teachers who are not on the payroll of the nursing career faculty are linked to the teaching process of the career. This heterogeneous composition is shown in Figure 1, and in general, the pedagogical and didactic training of the sciences is scarce and in most cases nil.

Teachers, as can be seen in the analysis of results, have different disciplinary training, so they must break a training paradigm when facing a new way of structuring their activity and interact with other knowledge in which they are not specialists, this is the which is why - in their way - they consider their subject the most important in the study plan. According to what was stated by the interviewees, there are insufficiencies in their pedagogical training to work the transversal axes of nursing and the training curricula of the professionals have an eminently disciplinary cut, being able to summarize that the experience in interdisciplinary work is insufficient and the work is scarce as a team to draw up strategies that improve, integrate and systematize the students' knowledge of the career.

A survey was applied to students of the second, third, and fourth levels of the nursing career. Of a population of 251 students of the three levels, 167 were surveyed, of them, only 73 identified which are the subjects that constitute the basic sciences of the curricular mesh of their career for $44 \%$ of positive responses, which infers that teachers do not have a correct impact on the orientation of interdisciplinary training and identification of their subject according to the field. 54\% (90 students) recognized the essential features of the importance of interdisciplinary relationships of basic sciences in their professional training and their transdisciplinary relationship with other subjects of their professional training, highlighting that:

1) It is clear to them that the subjects they receive must be related to each other and previously established links, the objects of study are approached integrally and the development of new methodological approaches for solving problems is promoted.

2) The interrelation of subjects is a dynamic process that aims to find solutions to different topics of research to apply their knowledge in the Knowledge Integration Project (PIS).

3) They are a very useful tool to fully understand the entire clinic of the patient and the human being to improve nursing knowledge and patient care, linking theories with practice.

These students understand that the knowledge of basic sciences will serve in the study of nursing since:

1) Basic sciences are essential in professional training, in biochemistry they study metabolism, all transformations, and all enzymatic chemical reactions that occur at the cellular level, and according to the cellular metabolism, so will the diseases that are suffered, the irregularities and imbalance of the body.

2) Morphophysiology teaches all the structures and functioning of the body of each organ that make up all systems.

3) Pharmacology integrates everything since knowledge of morphophysiology and biochemistry is needed to understand how drugs work in the body.

In a smaller percentage, but equally worrying, $46 \%$ (77 students) state that they have no idea what interdisciplinarity is, or how basic sciences influence their professional training, and how each subject is systematically taxed in the integration of your knowledge. In the revision of syllables of the curricular mesh of the nursing career of the basic sciences and other related subjects (Biosafety and Basic Nursing) actions are not conceived to achieve coherence and promote interdisciplinarity. As part of the work, the authors analyzed the contents of morphophysiology, biochemistry, and pharmacology I that are interrelated and that in turn

Velázquez, M. del R. H., Báez, A. A. L., Pérez, A. M., \& Luna, A. A. (2021). Educational innovation in the comprehensive training of nursing graduates. International Journal of Health Sciences, 5(1), 20-28. https://doi.org/10.29332/ijhs.v5n1.700 
contribute in a pertinent and coherent way to other subjects of the different years of the career and, especially, of the professional level or cycle (Pernas Gómez \& Uriarte Mulén, 2010), However, during the development of this research, no scientific evidence was found that exemplifies the interdisciplinarity in the teaching-learning process of the nursing career, especially in Ecuador. Result similar to that reflected by Elejalde Calderón et al. (2017), who report having found little scientific evidence that demonstrates, exemplifies, or describes how interdisciplinary nature is revealed in practice during the teaching-learning process of the nursing career (Elejalde Calderón et al., 2017).

Morphophysiology studies the form, structure, and function of the human organism; as well as the laws and principles that govern its organization, development, and relations with the external environment. Biochemistry studies the structure and behavior of biological molecules, which are carbon compounds that make up the various parts of the cell and carry out the chemical reactions that allow it to grow, feed, reproduce, and use and store energy. Pharmacology to aims study drugs and their action on the organism the processes of transformation of drugs once incorporated into the body, and its mechanism of action. The use and application of drug therapy constitute for the nursing staff one of the greatest responsibilities assumed in their interaction with the patient since the administration of the drugs indicated by the doctor is a permanent task, so it is essential to know the nature and origin of drugs, their mechanism of action, adverse reactions, precautions and drug interactions, their dosage, their form of presentation, and routes of administration. It is also part of their responsibility to educate the patient and family about the rational use of drugs and combat self-medication.

Links identified between the three subjects based on pharmacology:

a) Pharmaceutical forms and routes of administration. (The student applies the anatomical-structural characteristics that allow the absorption of drugs according to the route of administration)

b) Mechanisms of drug passage through cell membranes

c) Transport of drugs through membranes and biochemical mechanisms

d) Role of proteins at the level of membranes receptors

e) Biological membranes as body barriers

f) Metabolism (biotransformation) of drugs. Oxide-reduction reactions. Cytochrome P450 enzyme complex. Hydrolysis reactions. Reactions conjugation

g) Biochemical mechanisms of drug excretion. Renal excretion and biliary excretion. Biochemistry of the enterohepatic circulation

h) Membrane proteins as pharmacological

i) Receptors physiological and pharmacological receptors. Receptors coupled to ion channels. Receptors coupled to G proteins. Catalytic receptors that function as protein kinases. Receptors that regulate DNA transcription

j) Mediators of drug-receptor interaction. Effect of the membrane structure. Second messengers (cyclic AMP and cyclic GMP)

k) Acetylcholine and cholinergic receptors. Cholinergic agonists and antagonists

l) Adrenergic, dopaminergic, and cholinergic receptors

m) GABA

n) Enzymes as drug targets

o) Nucleic acids as drug targets

It was demonstrated that the integration of the subjects Morphophysiology, Biochemistry and Pharmacology I with each other and with Basic Nursing as the guiding subject of the level, is not enough, evidenced in the analysis of the syllables of the three subjects, where the development of activities that indicate said interrelation is not reflected, even though in the characterization of each subject if the interdisciplinary relationship is manifested. The interdisciplinarity of the basic cycle subjects must be assumed as a daily work from each subject, showing the student the points of convergence and the logical achievement of the content, how is it necessary for the nursing student to know the structure and function of the body human? (morphophysiology), the composition and biochemical functions of these organs and organ systems to finally understand in pharmacology the functioning of drugs in the body. It is the responsibility of the basic sciences to integrate the theoretical contents, with the important curricular function of providing the theoretical tools 
that support the study of health-related sciences, which will facilitate the understanding of the contents related to the specialty, which they receive students as the academic terms and curricular training units' progress.

All this without forgetting the need to develop in students the skills that allow them to solve the problems they face in their professional lives (Cuenca Doimeadios et al., 2013; Díaz Velis Martínez \& Ramos Ramírez, 2013) to thus contribute to the fulfillment of the objectives outlined in the curricular redesign of the career that express the training supported by epistemological and scientific knowledge in biological, humanistic and nursing sciences for the understanding of the problems of society, of the context and for their intervention, transformation, based on the objects and methodologies of the profession and that are possessors of cognitive competence, skills, and attitudes, which allow them to provide nursing care to the person and the community, according to norms and regulations established by the governing body.

It is evident than the need to motivate the student from the first years of the career, encourage them to the incessant search for knowledge and to acquire the necessary skills for their correct training, the process being driven by well-structured methodological designs and with the active participation of the teaching community. When evaluating the formulation and application of interdisciplinarity through frequent integrative activities, it was found that the planning of exercises, workshops, or independent works with these characteristics is scarce. For this reason, methodological actions are proposed that contribute to promoting the comprehensive training of students in the nursing career of UNESUM, which will guarantee greater scientific-professional preparation.

It is suggested to reorganize the teaching activity of the year group where the cognitive links between the disciplines of the level are worked, having as a central axis the contribution of basic sciences to the guiding discipline so that the student can concatenate the sequence of contents acquired in the different subjects and turn to integrate the knowledge in the subjects of the exercise of the profession. These activities can be developed through level collectives, career scientific activities, and career commissions (academic, research, and linkage), so that substantive functions are also interrelated, as expressed by various authors, (Pilot Porras et al. 2018; Alfonso Hidalgo \& Rodríguez Zamora, 2014; Gutiérrez Maydata et al. 2012; Rodríguez Milera et al. 2012), who agree that these actions enrich interdisciplinary work.

The interdisciplinarity in the first year of the nursing career can also be seen in the integrative knowledge projects (PIS), which begin with clinical cases with the application of the nursing care process and analysis of clinical cases of zoonotic diseases, where the student promotes health education in the community, for which he uses as a methodology a project with an interdisciplinary approach where the subjects of the level converge to achieve the same objective (Silva et al., 2013; Annan-Diab \& Molinari, 2017). This experience allows students to develop attitudes for teamwork, leadership, ethics, respect, discipline, among others, and also to perceive interdisciplinarity from the very development and preparation of the project to the resolution of the problem raised. However, and similar to that stated by Monsalve (s / f), it is worth noting the limited participation of teachers in the activity, mainly due to ignorance of interdisciplinarity and its fundamental role in the development and improvement of the quality of teaching in each subject (Salcedo Monsalve, s / f).

The heterogeneous composition of the teaching group at the level (doctors, nursing graduates, chemists, pedagogues, pharmacists) makes it necessary to plan teaching tasks with an interdisciplinary, integrative, and materialized approach in problematic situations such as clinical cases. These activities should be planned and systematically controlled and should be of collective development and approval. Only in this way will a satisfactory result be achieved that will result in the improvement of the quality of teaching. Professional training in nursing (and in any other career) needs the guidance of the empowered teaching group of the mission that corresponds to it, contextualized in the social reality, with a systemic approach and that is also dynamic, adjusted to the historical moment. It is no less true then that this task constitutes a challenge for those who direct the teaching-learning process and its protagonists (teachers and students). Through interviews with teachers and the application of surveys to students, it was found that there is a need to develop methodological career work aimed at disciplinary integration. Some shortcomings were detected, such as:

a) Inadequate perception of students about the important role that interdisciplinarity plays in their professional training, No

b) planning of methodological activities at the career level that promotes interdisciplinarity,

Velázquez, M. del R. H., Báez, A. A. L., Pérez, A. M., \& Luna, A. A. (2021). Educational innovation in the comprehensive training of nursing graduates. International Journal of Health Sciences, 5(1), 20-28. https://doi.org/10.29332/ijhs.v5n1.700 
c) In general, intra-teaching activities are planned and executed. subject, that is, with the contents of the subject and not the integration of contents and knowledge,

d) Teachers have no training or didactic or pedagogical preparation, in addition to coming from different areas of knowledge,

e) Students establish links between training disciplines However, they do not integrate the subjects,

f) Integrative Knowledge Projects (PIS) are designed for inter and transdisciplinary integration, however, both teachers and student's express dissatisfaction with their development and generally fail to establish integration,

g) Need to perform prop methodological proposals of concrete actions for interdisciplinarity from the first year of the degree

Therefore, it is necessary to propose actions that promote and contribute to the interdisciplinary approach from the basic sciences (biochemistry, morphophysiology, and pharmacology) to the disciplines of the practice of the profession in the nursing degree career, to strengthen the teaching-educational process and guarantee the comprehensive training of students. In this sense, and based on the shortcomings detected, it is proposed:

a) To develop periodic methodological activities in the year group to analyze the cognitive nodes and their interrelation,

b) To jointly develop integrative and interdisciplinary teaching tasks in the year group To

c) improve the work interdisciplinary in the PIS

For the success of the methodological proposal during its implementation, it is necessary to systematically control the teaching-learning process, which has as its main setting the classroom (teachers and students) and group meetings year (teachers of the level) (Romero Fernández et al., 2013). The planning, execution, and control of the teaching-methodological work that contributes to the improvement of the implementation of interdisciplinarity from the basic sciences in the nursing career, constitutes a necessary challenge to face from the chair, to fulfill the social order of training Nursing professionals who perform care, investigative and administrative functions at the primary, secondary and tertiary health care levels, contributing in actions of promotion, prevention and health rehabilitation with efficiency, responsibility, and high ethical and moral values, following the policies of the Ecuadorian state and good living (Placencia López et al., 2018; Santos Martínez et al., 2017).

For all the activities that are planned and that promote interdisciplinarity horizontally and vertically, take into account current trends in professional training in health, using teaching and innovative forms and methods, where the leading role is the student as a knowledge manager, guided by its teachers and involving in addition to professional services in student work services in the healthcare area. Integration of the contents of these basic sciences was achieved in the curricular redesign with an inter-and transdisciplinary approach, which has had a favorable impact on academic success and the quality of teacher preparation, which has a positive impact on students. Its correct application, development, and evaluation through the methodological work of the teachers favor the improvement, based on a growing decline in practical life training.

\section{Conclusion}

It is necessary to address interdisciplinarity as a necessary educational function from the different teaching scenarios, for which the teaching groups play an important role in the planning of the different methodological actions and the teacher-student binomial acquires the leading role in the execution of said actions. This interdisciplinary work from the first semester of the degree is one of the fundamental links in the integral formation of the nursing student since it is the basic sciences that prepare the "ground" for the subsequent approach to the disciplines of the exercise of the nursing profession.

Acknowledgments

We are grateful to two anonymous reviewers for their valuable comments on the earlier version of this paper. 


\section{References}

Alfonso Hidalgo, A., \& Rodríguez Zamora, L. (2014). Experiencia preliminar de nexos interdisciplinares entre Farmacología e Informática Médica en estudios médicos. EDUMECENTRO, 6(1), 145-159.

Annan-Diab, F., \& Molinari, C. (2017). Interdisciplinarity: Practical approach to advancing education for sustainability and for the Sustainable Development Goals. The International Journal of Management Education, 15(2), 73-83. https://doi.org/10.1016/j.ijme.2017.03.006

Chamberlain, D., Smith, A., Woollard, M., Colquhoun, M., Handley, A. J., Leaves, S., \& Kern, K. B. (2002). Trials of teaching methods in basic life support (3):: Comparison of simulated CPR performance after first training and at 6 months, with a note on the value of re-training. Resuscitation, 53(2), 179-187. https://doi.org/10.1016/S0300-9572(02)00025-4

Cuenca Doimeadios, E., Reyes Hernández, D., Ellis Yards, M., Navarro Hernández, M., \& Alvelo Pérez, D. (2013). Recursos de aprendizaje en la asignatura de Psiquiatría para la formación del Médico Integral Comunitario. Educ Med Super, 27(1), 31-37.

Díaz Velis Martínez, E., \& Ramos Ramírez, R. (2013). Reflexiones orientadoras sobre la Didáctica Especial en las asignaturas clínicas. EDUMECENTRO, 5(1), 30-46.

Elejalde Calderón, M., Valcárcel Izquierdo, N., \& Sandín Chávez, W. (2017). Importancia de la Interdisciplinariedad en el proceso de formación de la carrera de Enfermería. Revista Cubana de Tecnología de la Salud, 8(2), 90-96.

Guasch, T., Alvarez, I., \& Espasa, A. (2010). University teacher competencies in a virtual teaching/learning environment: Analysis of a teacher training experience. Teaching and Teacher Education, 26(2), 199-206. https://doi.org/10.1016/j.tate.2009.02.018

Gutiérrez Maydata, A., Wong Orfila, T., Pérez de Armas, A., \& Villar Valdés, M. (2012). Propuesta para dar continuidad al perfeccionamiento de la Morfofisiología en la carrera de Medicina. EDUMECENTRO, 133-46, 133-46.

Kyriakides, L., Creemers, B. P., \& Antoniou, P. (2009). Teacher behaviour and student outcomes: Suggestions for research on teacher training and professional development. Teaching and teacher education, 25(1), 1223. https://doi.org/10.1016/j.tate.2008.06.001

Martínez Trujillo, N., \& Torres Esperón, M. (2014). La interdisciplinariedad en enfermería y sus oportunidades de aplicación en Cuba. Revista Cubana de Salud Pública, 40(1), 85-95.

Pernas Gómez, M., \& Uriarte Mulén, O. (2010). Inter y transdisciplinariedad de las ciencias básicas en el nuevo modelo de formación de enfermeros. Revista Cubana de Enfermería, 26(2), 63-70.

Piloto Porras, D., González Miló, A., González González, M., Ortiz Castillo, L., \& González Rodríguez, R. (2018). Interdisciplinariedad desde la disciplina Medicina General Integral hacia las ciencias Básicas Biomédicas. Revista Universidad Médica Pinareña, 14(3), 257-266.

Placencia López, M., Calderón Macías, L., Baque Mendoza, C., Pincay Cañarte, M., Solórzano Solórzano, S., \& Villacreses Veliz, G. (2018). Rediseño curricular de la carrera de enfermería. Área de Innovación y Desarrollo, SL 3Ciencias.

Rodríguez Milera, J., Pernas Gómez, M., Montano Luna, J., Lima Sarmiento, L., Díaz Molleda, M., \& Pérez Esquivel, G. (2012). Valoración de las actividades de orientación de contenido de la disciplina Morfofisiología Humana. Educ Med Super, 26(2).

Romero Fernández, M., Santos Muñoz, L., Hidalgo Ruiz, M., Rodríguez Prado, A., \& Rodríguez Somoza, W. (2013). Enfoque integrador de estrategias curriculares desde Farmacología I y su influencia en el proceso docente. EDUMECENTRO, 5(2).

Santos Martínez, R., Alfonso Hidalgo, A., Quintanilla Opizo, O., Chaviano Herrera, O., García Ávila, I., \& Valdés Utrera, J. (2017). Trabajo metodológico: reclamo para lograr interdisciplinariedad desde el colectivo año de la carrera de Medicina. EDUMECENTRO, 9(1), 175-189.

Silva, F. N., Rodrigues, F. A., Oliveira Jr, O. N., \& Costa, L. D. F. (2013). Quantifying the interdisciplinarity of scientific journals and fields. Journal of Informetrics, 7(2), 469-477. https://doi.org/10.1016/j.joi.2013.01.007

Wik, L., Myklebust, H., Auestad, B. H., \& Steen, P. A. (2002). Retention of basic life support skills 6 months after training with an automated voice advisory manikin system without instructor involvement. Resuscitation, 52(3), 273-279. https://doi.org/10.1016/S0300-9572(01)00476-2

Velázquez, M. del R. H., Báez, A. A. L., Pérez, A. M., \& Luna, A. A. (2021). Educational innovation in the comprehensive training of nursing graduates. International Journal of Health Sciences, 


\section{Biography of Authors}

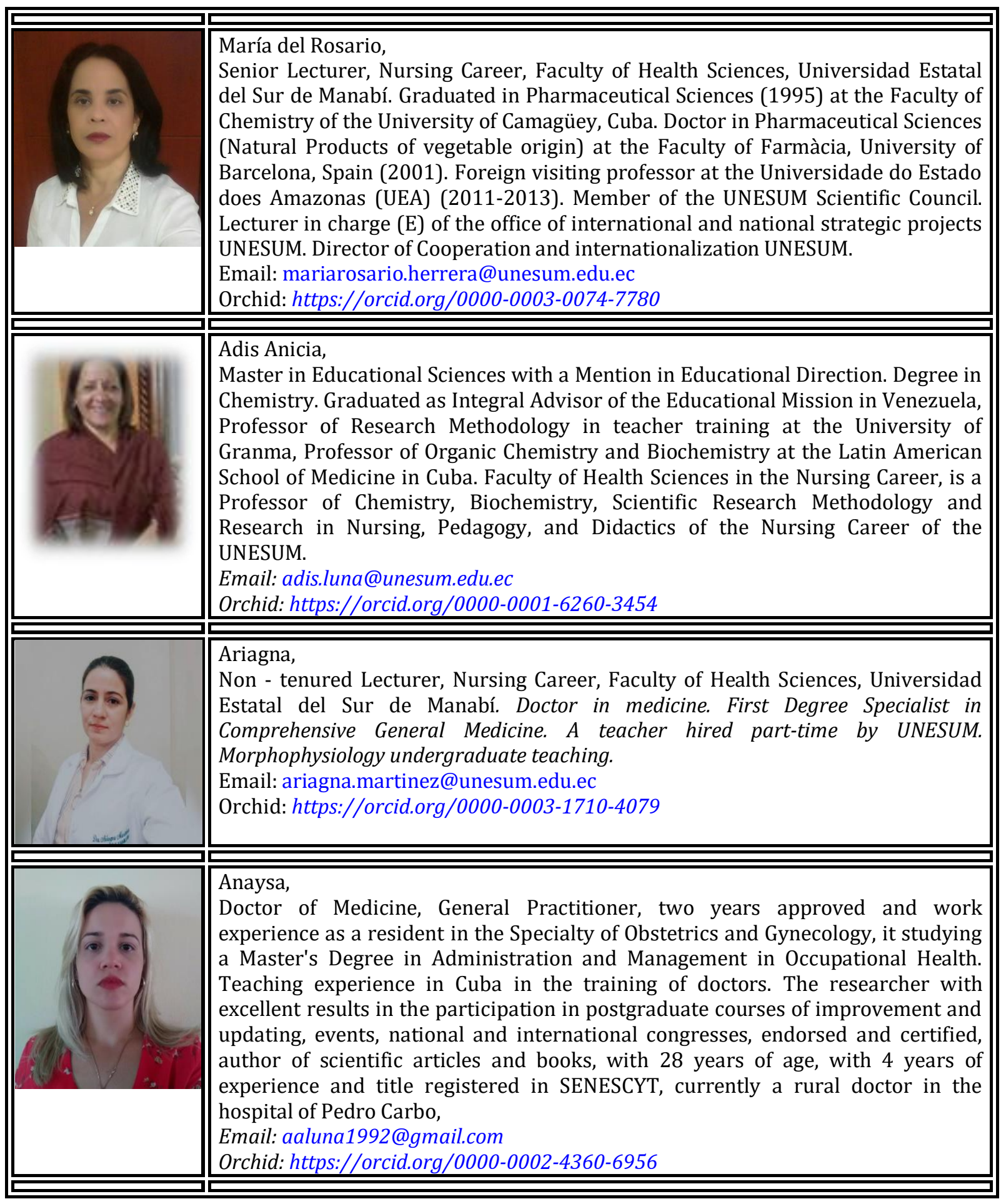

